\title{
OCCUPATIONAL NOISE AND CARDIOVASCULAR RISK BY EXAGGERATED BLOOD PRESSURE RESPONSE AT EXERCISE IN EXPOSED WORKERS
}

\author{
By \\ Fahmy, F.C., Abbas, F. and Noweir, K. \\ Occupational Health Department, High Institute of Public Health, \\ Alexandria University, Egypt.
}

\begin{abstract}
:
The relationship between occupational noise exposure and hypertension as well as other coronary risk factors is recently highlighted. The objective of this study was to investigate if exaggerated blood pressure response to exercise testing can be used as a predictive tool for cardiovascular risk stratification in relation to occupational noise exposure.

Subjects and Methods: Normotensive male workers free from diabetes and cardiovascular disease, in one of the industrial facilities in Alexandria were included in the study. Personal noise exposure levels were measured for workers exposed to noise in compressors and maintenance workshops as mean time weighted average (TWA). Three groups were considered each one comprised 50 workers representing high noise exposed group (compressor operators with TWA 90 $\pm 4 \mathrm{dBA}$ ), low noise exposed group (maintenance workers with TWA 79 $\pm 6 \mathrm{dBA}$ ) and non exposed group from administrative staff. After ethical consideration and obtaining a written consent, all participants were subjected to a questionnaire about personal and occupational data including perceived noise annoyance. Conventional coronary risk factors were measured. A standard symptom limited ergometer exercise test with Bruce protocol was performed and peak exercise hemodynamic variables were defined. Exaggerated blood pressure response at exercise was defined as peak SBP > $200 \mathrm{mmHg}$ and/or peak $\mathrm{DBP}>95 \mathrm{mmHg}$.
\end{abstract}

Results: The three groups were similar in socio-demographic data. Exaggerated BP response at exercise was significantly more prevalent among high noise exposed 
group in comparison to other groups. The sensitivity and specificity of the suggested test in predicting high risk cases (those with $\geq 3$ risk factors) were $77.5 \%$ and $84.6 \%$ respectively. Logistic regression analysis of results of the predictive test showed significant relation to noise level, perceived noise annoyance, resting HR and LDLcholesterol $(\mathrm{P}<0.05$ for all $)$.

Conclusion and recommendations: Exaggerated BP response to exercise can be used as a predictive tool for early detection of high risk noise exposed workers in occupational health preventive programs. Noise exposure levels should be reduced to safe health criteria.

Key words: Noise exposure, Cardiovascular effects, Hypertensive response, Exercise testing, Extra-auditory noise effects.

This work was presented as a poster in American Public Health Association the $138^{\text {th }}$ meeting (November 6 - 10, 2010 in Denever, CO) at the session: 2069.0, Occupational health and safety posters - International. (Abstract) htt:/apha.confex.com/apha/138am/ webprogram/Paper230434.html

\section{Introduction}

Occupational noise exposure is a common hazard in many industries and work places, with its known auditory and possible non-auditory effects (Thompson, 1993). Several epidemiologic studies have reported that exposure to noise is associated with cardiovascular disease, especially coronary heart disease (Davies, et al., 2005; Virkkumen, et al., 2005; Willich, et al., 2006) and hypertension (Chang, et al., 2003; Lusk, et al., 2002; Tomei, et al., 2000). A recent meta-analysis for cardiovascular changes across different levels of occupational noise exposure in comparative studies reported significant high prevalence of both hypertension and electrocardiographic abnormalities among high exposure workers (Tomei, et al., 2010).

Noise exposure can induce biochemical, physiological and/or psychosocial changes through a stress mediated mechanism due to the perceived annoyance. Sense of annoyance differs according to personal characteristics and may be influenced by lifestyle and genetic predisposition, increasing the overall cardiovascular risk (Babisch, et al., 2003; Ljungberg, and Neely, 2007). Most studies for assessment of cardiovascular risk and occupational noise exposure are based on measurements of already established risk factors such as hypertension, increased heart rate, and dyslipidemias among the exposed workers (Abbate, 2002; Giordano, 2001). 
An exaggerated blood pressure response to dynamic exercise testing among normotensive subjects was found in many follow-up studies to be significantly related to the risk of future hypertension (Dlin, et al., 1983; Manolio, et al., 1994; Singh, et al., 1999); as well as, cardiovascular mortality (Filipovsky, et al., 1992; Kjeldsen, et al., 2001).

Cardiovascular risk stratification for those occupationally exposed to noise is still under investigation. The objective of this study was to investigate if exaggerated blood pressure response to exercise testing can be used as a predictive test for cardiovascular risk stratification in relation to occupational noise exposure.

\section{Subjects and Methods}

\section{Study design and setting:}

A cross-sectional study was conducted in one of the industrial facilities for fertilizer manufacturing in Alexandria. Noisy departments including compressors and maintenance workshops as well as the non-exposed administrative department were included in the study.

\section{Exposure measurements:}

Occupational hygiene data of the company was obtained from records revealing that there was no ototoxic or cardiotoxic chemicals present in the work environment of this plant.

Noise exposure was continuously measured using a personal noise dosimeter (Quest Technologies, inc. USA, Approval No 18-A040003-0) after acoustic calibration using acoustic Quest Technologies Calibrator Model QC-10-QC-20. Five measurements for each of the two exposed groups were obtained according to the standard procedure. Results were expressed as full-shift time weighted average sound pressure level in decibels (TWA, dBA) (Hassall, and Zaveri, 1979). Compressor operators and maintenance workers were exposed to TWA levels of $90 \pm 4 \mathrm{dBA}$ and $79 \pm 6 \mathrm{dBA}$ representing high and low noise exposed groups respectively.

\section{Study population:}

Male workers, aged less than 50 years, with normal resting $\mathrm{BP}(\mathrm{SBP}<140$ $\mathrm{mmHg}$ and DBP $<90 \mathrm{mmHg}$ not taking antihypertensive treatment) according to the European guidelines (ESH and ESC guidelines 2007), with no history of diabetes and without cardiovascular disease were included in the study. All workers meeting the inclusion criteria from compressor operators (high noise exposed group) comprised 50 workers. Two other groups each of 50 workers of matched 
socio-demographic characteristics from maintenance workers (low noise exposed group) and administrative staff without occupational noise exposure (non-exposed group) were included.

\section{Study methods:}

After ethical consideration, all participants gave a written consent to participate in the study providing them with detailed explanation of the procedure.

\section{1) Questionnaire:}

Each participant in the study sample was subjected to a questionnaire about personal, medical and occupational data especially duration of employment and use of ear protective equipment. Perceived noise annoyance was categorized using the Borg rating scale which ranges from 0 (nothing at all) to 10 (extremely strong) (Borg, 1998). Smoking history was taken and smoking index (SI) was calculated (number of daily cigarettes $x$ years of smoking). Physical activity and family history of premature coronary artery disease (CAD) before the age of 55 years were inquired about. (Rose, et al., 1982)

\section{2) Clinical examination:}

Anthropometric data including height (Ht) and weight (Wt) were measured and body mass index (BMI $\mathrm{kg} / \mathrm{m} 2$ ) was calculated. Obesity was diagnosed for those with BMI of $30 \mathrm{~kg} / \mathrm{m} 2$ and more (WHO, 2006). Resting HR, resting SBP and resting DBP were measured according to the ESH and ESC guidelines 2007.

\section{3) Biological testing:}

Fasting venous blood samples were collected by vein-puncture to determine fasting blood glucose, total cholesterol (TC), LDL-cholesterol (LDL-C), HDLcholesterol (HDL-C) and triglycerides (TG) by the standard enzymatic methods (Friedewold, et al., 1972). Cases with fasting glucose $>110 \mathrm{mg} / \mathrm{dl}$ were excluded from the study due to impaired glucose tolerance (Balkau, et al., 1998). Risk levels were considered at TC $\geq 200 \mathrm{mg} / \mathrm{dl}$ and/or LDL-C $\geq 130 \mathrm{mg} / \mathrm{dl}$ (hypercholesterolemia), HDL-C $<35 \mathrm{mg} / \mathrm{dl}$ and TG $\geq 150 \mathrm{mg} / \mathrm{dl}$ (hypertriglyceridemia) (NCEP 1994).

\section{4) Ergometer exercise test:}

A standard symptom limited ergometer exercise test with Bruce protocol was done and peak exercise hemodynamic variables were defined including peak HR, percent achieved of the maximal predicted heart rate for age $(\%$ MPHR = peak HR / $220-$ age in years \%), exercise time (min) and work capacity METs (1 MET, METablic equivalent $=3.5 \mathrm{ml}$ of $\mathrm{O} 2 / \mathrm{kg} /$ minute i.e. basal oxygen consumption) (Buchfuhrer, 
et al., 1983). Blood pressure was measured every minute during exercise by mercury sphyngomanometer. Peak SBP and peak DBP were recorded. Exaggerated blood pressure response at exercise was defined as peak $\mathrm{SBP}>200 \mathrm{mmHg}$ and/or peak DBP > 95 mmHg (Dlin, et al., 1983; Ilia, et al., 1998).

\section{Statistical analysis}

Data were analyzed using SPSS (statistical package for Social Sciences) version 17. Continuous variables were expressed as means and standard deviations; meanwhile, qualitative data were defined as numbers and percentages. Comparison between the three groups of high noise exposed, low noise exposed and non exposed groups regarding the different risk factors was done using the appropriate test of significance (Anova and $\mathrm{X} 2$ tests). Meanwhile, comparison between two groups was done with $\mathrm{t}$ and $\mathrm{X} 2$ tests. Logistic regression analysis was done with exaggerated BP response as the dependent variable for significant risk factors in univariate analysisconsidering noise level (nonexposed $=1$, low noise $=2$ and high noise $=$ $3)$. The sensitivity, specificity and accuracy of this test in risk stratification of cases with $\geq 3$ risk factors (including current smoking, BMI $\geq 30 \mathrm{Kg} / \mathrm{m} 2$, hypercholesterolemia, hypertriglyceridemia, positive family history of premature CAD and physical inactivity) were calculated according to the previously mentioned definitions. The level of significance for $\mathrm{p}$ value was considered at $<0.05$.

\section{Results}

Characteristics and measurements of the studied population by noise level:

The age of the studied population ranged from 32 to 49 years. The three groups were similar in anthropometric measurements (Ht, Wt and BMI), sociodemographic data (education and marital status) and personal habits (smoking and physical activity) as well as, family history of premature CAD. Occupational history revealed that there was no significant difference for the duration of employment between the three groups; meanwhile, the perceived noise annoyance scores showed a statistically significant difference between the studied groups. The highest score was reported by those exposed to high noise followed by those exposed to low noise in comparison to the non exposed group ( $\mathrm{p}<$ 0.001). [Table 1]

None of the exposed workers either in the high or low exposed groups gave a positive history for use of noise-personal protective equipment. 
Resting hemodynamic measurements showed that resting HR was statistically significantly higher among high noise exposed workers in comparison to low noise exposed workers and non exposed group $(\mathrm{p}$ $<0.001)$. No significant differences were observed between the three groups for resting SBP and resting DBP. On the other hand, peak hemodynamic measurements revealed statistically significant differences for peak SBP and peak DBP among the studied groups with the highest mean values among high noise exposed group followed by low noise exposed group and the lowest were recorded for non exposed group ( $\mathrm{p}<0.001$ for both). Also, exaggerated BP response at exercise was more significantly prevalent by the higher level of noise exposure $(\mathrm{p}<0.001)$. Other variables including \%MPHR, exercise time and work units (METs) were not significant between the three groups. Biochemical analysis revealed statistically significant differences for TC and LDL-C with higher means by the higher level of noise exposure ( $p<0.001 \& 0.037$ respectively); however, HDL-C, TG and fasting glucose were not significant. [Table 2]

\section{Risk factors by exaggerated BP} response at exercise:

Exaggerated BP responders at exercise in the studied population were significantly more perceiving noise annoyance, with higher $\mathrm{Wt}$, with greater BMI and with higher SI than normal responders ( $p<0.001$, $0.01 \& 0.001$ respectively). Those with positive family history of premature CAD and physical inactivity were significantly more prevalent among exaggerated BP responders in comparison to normal responders ( $\mathrm{p}<0.013 \& 0.018$ respectively). However, no significant differences were observed for age, duration of employment and other socio-demographic data. Mean values of resting HR, SBP and DBP were observed to be statistically significantly higher among exaggerated BP responders than normal responders. Meanwhile, exercise time and work capacity units (METs) showed significantly lower values in exaggerated responders than normal responders ( $\mathrm{p}<0.001$ for all). Other coronary risk factors that showed statistical significance in relation to exaggerated $\mathrm{BP}$ response at exercise were the higher levels of TC, LDL-C and TG ( $\mathrm{p}<0.001$ for all). No significant differences were observed for \%MPHR, fasting glucose and HDL-C. [Table 3]

Sensitivity, specificity and accuracy of exaggerated BP response at exercise as a predictive test in relation to stratification of cases with 3 risk factors or more were calculated. It revealed a sensitivity of 
$77.5 \%$, a specificity of $84.6 \%$ and an noise annoyance, resting HR and LDL-C accuracy of $82.7 \%$ respectively for the test. $\quad(\mathrm{R}=0.58, \mathrm{p}=0.04,0.03,0.009 \& 0.001$ [Table 4]

Logistic regression analysis with exaggerated $\mathrm{BP}$ response at exercise as the dependent variable demonstrated significant relation to noise level, perceived respectively) even after adjustment for BMI, SI, family history of premature CAD and physical inactivity $(\mathrm{p}=0.611,0.814$, $0.314 \& 0.581$ respectively). [Table 5] 
Table 1: Summary characteristics of the studied population by noise level.

\begin{tabular}{|l|c|c|c|c|c|}
\hline Variables & $\begin{array}{c}\text { High noise } \\
\text { exposed group } \\
(\mathbf{n}=\mathbf{5 0})\end{array}$ & $\begin{array}{c}\text { Low noise } \\
\text { exposed group } \\
(\mathbf{n}=50)\end{array}$ & $\begin{array}{c}\text { Non-exposed } \\
\text { group } \\
(\mathbf{n}=50)\end{array}$ & Test of Sig. & $\mathbf{p}$ \\
\hline $\begin{array}{l}\text { Age (years) } \\
\text { Mean } \pm \text { SD }\end{array}$ & $39.38 \pm 6.50$ & $39.14 \pm 7.41$ & $38.60 \pm 7.02$ & 0.647 & 0.525 \\
\hline $\begin{array}{l}\text { Duration of } \\
\text { employment (years) } \\
\text { Mean } \pm \text { SD }\end{array}$ & $13.80 \pm 5.61$ & $14.14 \pm 5.94$ & $13.28 \pm 5.50$ & 1.582 & 0.209 \\
\hline $\begin{array}{l}\text { Perceived noise } \\
\text { annoyance (score } \\
\text { 0/10) Mean } \pm \text { SD }\end{array}$ & $5.58 \pm 1.82$ & $4.58 \pm 1.67$ & $2.58 \pm 1.79$ & 37.730 & $0.000 *$ \\
\hline $\begin{array}{l}\text { Height (cm) } \\
\text { Mean } \pm \text { SD }\end{array}$ & $178.96 \pm 5.77$ & $173.92 \pm 6.72$ & $174.14 \pm 7.54$ & 1.390 & 0.252 \\
\hline $\begin{array}{l}\text { Weight (kg) } \\
\text { Mean } \pm \text { SD }\end{array}$ & $85.12 \pm 10.72$ & $82.90 \pm 12.76$ & $83.36 \pm 15.01$ & 0.409 & 0.665 \\
\hline $\begin{array}{l}\text { BMI (kg/m }) \\
\text { Mean } \pm \text { SD }\end{array}$ & $27.50 \pm 3.23$ & $27.37 \pm 3.66$ & $27.38 \pm 3.80$ & 0.022 & 0.979 \\
\hline $\begin{array}{l}\text { SI (daily cigarettes x } \\
\text { years) } \\
\text { Mean } \pm \text { SD }\end{array}$ & $150.30 \pm 208.89$ & $116.02 \pm 183.05$ & $110.40 \pm 181.68$ & 0.635 & 0.51 \\
\hline $\begin{array}{l}\text { Current smokers } \\
\text { N(\%) }\end{array}$ & $28(56 \%)$ & $24(48 \%)$ & $21(42 \%)$ & 1.975 & 0.373 \\
\hline $\begin{array}{l}\text { High education } \\
\text { N(\%) }\end{array}$ & $28(56 \%)$ & $22(44 \%)$ & $32(64 \%)$ & 4.089 & 0.129 \\
\hline $\begin{array}{l}\text { Married } \\
\text { N(\%) }\end{array}$ & $36(72 \%)$ & $36(72 \%)$ & $30(60 \%)$ & 4.536 & 0.336 \\
\hline $\begin{array}{l}\text { Family history of } \\
\text { premature CAD } \\
\mathbf{N}(\%)\end{array}$ & $16(32 \%)$ & $16(32 \%)$ & $19(38 \%)$ & 0.535 & 0.765 \\
\hline $\begin{array}{l}\text { Physically inactive } \\
\text { N(\%) }\end{array}$ & $17(34 \%)$ & $17(34 \%)$ & $15(30 \%)$ & 6.227 & 0.398 \\
\hline
\end{tabular}

$* \mathrm{P}<0.05$ 
Table 2: Hemodynamic and biochemical measurements by noise level.

\begin{tabular}{|c|c|c|c|c|c|}
\hline Variables & $\begin{array}{c}\text { High noise } \\
\text { exposed group } \\
(\mathbf{n}=50)\end{array}$ & $\begin{array}{c}\text { Low noise } \\
\text { exposed group } \\
(\mathbf{n}=50)\end{array}$ & $\begin{array}{c}\text { Non-exposed } \\
\text { group } \\
(\mathrm{n}=50)\end{array}$ & $\begin{array}{l}\text { Test of } \\
\text { Sig. }\end{array}$ & $\mathbf{p}$ \\
\hline $\begin{array}{l}\text { Resting HR (beat/min) } \\
\text { Mean } \pm \text { SD }\end{array}$ & $76.10 \pm 5.21$ & $72.02 \pm 6.15$ & $71.74 \pm 5.07$ & 9.848 & $0.000 *$ \\
\hline $\begin{array}{l}\text { Resting SBP }(\mathbf{m m H g}) \\
\text { Mean } \pm \text { SD }\end{array}$ & $123.00 \pm 9.58$ & $122.10 \pm 8.87$ & $120.60 \pm 7.26$ & 0.988 & 0.375 \\
\hline $\begin{array}{l}\text { Resting DBP }(\mathrm{mmHg}) \\
\text { Mean } \pm \text { SD }\end{array}$ & $80.20 \pm 4.16$ & $79.30 \pm 4.74$ & $79.00 \pm 4.40$ & 0.989 & 0.374 \\
\hline $\begin{array}{l}\% \text { MPHR } \\
\text { Mean } \pm \text { SD }\end{array}$ & $96.20 \pm 15.09$ & $97.46 \pm 12.90$ & $98.91 \pm 3.08$ & 0.693 & 0.502 \\
\hline $\begin{array}{l}\text { Peak SBP }(\mathrm{mmHg}) \\
\text { Mean } \pm \text { SD }\end{array}$ & $187.20 \pm 21.12$ & $175.30 \pm 15.20$ & $169.50 \pm 14.15$ & 13.921 & $0.000 *$ \\
\hline $\begin{array}{l}\text { Peak DBP }(\mathrm{mmHg}) \\
\text { Mean } \pm \text { SD }\end{array}$ & $95.00 \pm 10.15$ & $89.60 \pm 9.14$ & $86.60 \pm 6.10$ & 2.147 & $0.000 *$ \\
\hline $\begin{array}{l}\text { Exercise time (min) } \\
\text { Mean } \pm \text { SD }\end{array}$ & $8.97 \pm 1.46$ & $9.00 \pm 1.44$ & $9.63 \pm 1.77$ & 2.812 & 0.063 \\
\hline $\begin{array}{l}\text { Work capacity units } \\
\text { (METs) } \\
\text { Mean } \pm \text { SD }\end{array}$ & $10.10 \pm 1.57$ & $10.18 \pm 1.52$ & $10.92 \pm 1.81$ & 2.817 & 0.064 \\
\hline $\begin{array}{l}\text { Fasting glucose }(\mathrm{mg} / \mathrm{d}) \\
\text { Mean } \pm \text { SD }\end{array}$ & $92.18 \pm 8.82$ & $92.40 \pm 9.97$ & $89.04 \pm 6.97$ & 2.348 & 0.099 \\
\hline $\begin{array}{l}\text { Total cholesterol }(\mathrm{mg} / \mathrm{dl}) \\
\text { Mean } \pm \text { SD }\end{array}$ & $194.18 \pm 28.14$ & $177.78 \pm 24.49$ & $174.04 \pm 25.24$ & 8.483 & $0.000^{*}$ \\
\hline $\begin{array}{l}\text { LDL- cholesterol (mg/dl) } \\
\text { Mean } \pm \text { SD }\end{array}$ & $113.16 \pm 26.96$ & $104.96 \pm 25.94$ & $101.44 \pm 28.01$ & 3.483 & $0.037^{*}$ \\
\hline $\begin{array}{l}\text { HDL- cholesterol (mg/dl) } \\
\text { Mean } \pm \text { SD }\end{array}$ & $46.64 \pm 10.51$ & $43.90 \pm 9.65$ & $45.96 \pm 10.90$ & 0.947 & 0.390 \\
\hline $\begin{array}{l}\text { Triglycerides }(\mathrm{mg} / \mathrm{dl}) \\
\text { Mean } \pm \text { SD }\end{array}$ & $155.72 \pm 47.73$ & $143.50 \pm 35.26$ & $140.44 \pm 43.69$ & 1.806 & 0.168 \\
\hline $\begin{array}{l}\text { Exaggerated BP at } \\
\text { exercise } \\
\mathrm{N}(\%) \\
\end{array}$ & $25(50 \%)$ & $11(22 \%)$ & $4(8 \%)$ & 23.386 & $0.000 *$ \\
\hline
\end{tabular}

$* \mathrm{P}<0.05$ 
Table 3: Summary characteristics and measurements of the studied population according to exaggerated BP response at exercise.

\begin{tabular}{|c|c|c|c|c|}
\hline Variables & $\begin{array}{c}\text { Exaggerated BP } \\
\text { responders } \\
(\mathrm{n}=40)\end{array}$ & $\begin{array}{c}\text { Normal } \\
\text { responders } \\
(\mathbf{n}=110)\end{array}$ & $\begin{array}{l}\text { Test of } \\
\text { Sig. }\end{array}$ & $\mathbf{p}$ \\
\hline $\begin{array}{l}\text { Age (years) } \\
\text { Mean } \pm \text { SD }\end{array}$ & $39.81 \pm 6.29$ & $38.30 \pm 7.01$ & 0.861 & 0.321 \\
\hline $\begin{array}{l}\text { Duration of employment (years) } \\
\text { Mean } \pm \text { SD }\end{array}$ & $14.24 \pm 5.19$ & $13.18 \pm 5.53$ & 0.622 & 0.561 \\
\hline $\begin{array}{l}\text { Perceived noise annoyance (score } 0 / 10 \text { ) } \\
\text { Mean } \pm \text { SD }\end{array}$ & $5.75 \pm 1.34$ & $3.70 \pm 2.13$ & -5.685 & $0.000 *$ \\
\hline $\begin{array}{l}\text { Height }(\mathrm{cm}) \\
\text { Mean } \pm \text { SD }\end{array}$ & $174.78 \pm 5.81$ & $174.64 \pm 7.06$ & -0.111 & 0.912 \\
\hline $\begin{array}{l}\text { Weight }(\mathrm{kg}) \\
\text { Mean } \pm \text { SD }\end{array}$ & $87.55 \pm 11.69$ & $82.43 \pm 13.09$ & -2.178 & $0.031 *$ \\
\hline $\begin{array}{l}\text { BMI }\left(\mathbf{k g} / \mathbf{m}^{2}\right) \\
\text { Mean } \pm \text { SD }\end{array}$ & $28.64 \pm 3.30$ & $26.97 \pm 3.55$ & -2.593 & $0.010 *$ \\
\hline $\begin{array}{l}\text { SI (daily cigarettes } x \text { years) } \\
\text { Mean } \pm \text { SD }\end{array}$ & $153.88 \pm 230.27$ & $115.28 \pm 174.84$ & -1.094 & $0.001 *$ \\
\hline $\begin{array}{l}\text { Current smokers } \\
\mathrm{N}(\%)\end{array}$ & $22(55.0 \%)$ & $51(46.4 \%)$ & 0.876 & 0.349 \\
\hline $\begin{array}{l}\text { High education } \\
\mathrm{N}(\%)\end{array}$ & $18(45.0 \%)$ & $64(58.2 \%)$ & 2.057 & 0.152 \\
\hline $\begin{array}{l}\text { Married } \\
\mathrm{N}(\%)\end{array}$ & $30(75 \%)$ & $72(65.5 \%)$ & 2.651 & 0.103 \\
\hline $\begin{array}{l}\text { Family history of premature CAD } \\
\mathrm{N}(\%)\end{array}$ & $20(50.0 \%)$ & $31(28.2 \%)$ & 6.223 & $0.013 *$ \\
\hline $\begin{array}{l}\text { Physically inactive } \\
\text { N }(\%)\end{array}$ & $18(45.0 \%)$ & $31(28.2 \%)$ & 10.096 & $0.018 *$ \\
\hline $\begin{array}{l}\text { Resting HR (beat } / \mathrm{min}) \\
\text { Mean } \pm \text { SD }\end{array}$ & $77.10 \pm 4.90$ & $71.90 \pm 5.51$ & -5.257 & $0.000 *$ \\
\hline $\begin{array}{l}\text { Resting SBP }(\mathrm{mmHg}) \\
\text { Mean } \pm \text { SD }\end{array}$ & $128.38 \pm 8.20$ & $119.55 \pm 7.53$ & -6.203 & $0.000 *$ \\
\hline $\begin{array}{l}\text { Resting DBP }(\mathrm{mmHg}) \\
\text { Mean } \pm \text { SD }\end{array}$ & $81.88 \pm 3.70$ & $78.64 \pm 4.39$ & -4.161 & $0.000 *$ \\
\hline $\begin{array}{l}\text { \%MPHR } \\
\text { Mean } \pm \text { SD }\end{array}$ & $96.89 \pm 9.31$ & $97.75 \pm 12.28$ & 0.404 & 0.687 \\
\hline $\begin{array}{l}\text { Exercise time (min) } \\
\text { Mean } \pm \text { SD }\end{array}$ & $8.25 \pm 1.22$ & $9.55 \pm 1.56$ & 4.782 & $0.000 *$ \\
\hline $\begin{array}{l}\text { Work capacity units (METs) } \\
\text { Mean } \pm \text { SD }\end{array}$ & $9.33 \pm 1.23$ & $10.79 \pm 1.64$ & 5.156 & $0.000 *$ \\
\hline $\begin{array}{l}\text { Fasting Glucose }(\mathrm{mg} / \mathrm{d}) \\
\text { Mean } \pm \text { SD }\end{array}$ & $93.15 \pm 9.09$ & $90.50 \pm 8.56$ & -1.649 & 0.101 \\
\hline $\begin{array}{l}\text { Total cholesterol }(\mathrm{mg} / \mathrm{dl}) \\
\text { Mean } \pm \text { SD }\end{array}$ & $204.98 \pm 26.57$ & $173.65 \pm 22.38$ & -7.204 & $0.000 *$ \\
\hline $\begin{array}{l}\text { LDL- cholesterol (mg/dl) } \\
\text { Mean } \pm \text { SD }\end{array}$ & $128.23 \pm 30.22$ & $99.72 \pm 22.66$ & -5.554 & $0.000 *$ \\
\hline $\begin{array}{l}\text { HDL- cholesterol }(\mathrm{mg} / \mathrm{dl}) \\
\text { Mean } \pm \text { SD }\end{array}$ & $44.63 \pm 10.43$ & $45.82 \pm 10.37$ & 0.622 & 0.535 \\
\hline $\begin{array}{l}\text { Triglycerides }(\mathrm{mg} / \mathrm{dl}) \\
\text { Mean } \pm \text { SD }\end{array}$ & $166.40 \pm 54.05$ & $139.34 \pm 35.48$ & -3.559 & $0.001 *$ \\
\hline
\end{tabular}

$* \mathrm{P}<0.05$ 
Table 4: Sensitivity, specificity and accuracy of the predictive test in relation to stratification of cardiovascular risk.

\begin{tabular}{|l|c|c|c|c|c|}
\hline \multirow{2}{*}{ Risk factors } & \multicolumn{4}{|c|}{ BP Response } & \multirow{2}{*}{ Total } \\
\cline { 2 - 6 } & \multicolumn{2}{|c|}{$\begin{array}{c}\text { Exaggerated BP } \\
\text { responders }\end{array}$} & \multicolumn{2}{c|}{ Normal responders } & \multicolumn{1}{c|}{} \\
\cline { 2 - 6 } & No. & $\%$ & No. & $\%$ & 48 \\
\hline \multirow{2}{*}{ < 3 risk factors } & 31 & 77.5 & 17 & 15.4 & 112 \\
\hline Total & 9 & 22.5 & 93 & 84.6 & 150 \\
\hline
\end{tabular}

Sensitivity $=77.5 \%$

Specificity $=84.6 \%$

Accuracy $=82.7 \%$

Table 5: Logistic regression model for the predictive test as the dependent variable in the studied population.

\begin{tabular}{|l|c|c|c|c|c|}
\hline Variables & B & SE & Beta & T & P \\
\hline Constant & -1.661 & 0.386 & & -4.307 & 0.000 \\
\hline Noise level (groups 1-3) & 0.093 & 0.045 & 0.173 & 2.069 & 0.040 \\
\hline Perceived noise annoyance (score 0/10) & 0.038 & 0.018 & 0.186 & 2.184 & 0.031 \\
\hline Resting HR (beat/min) & 0.015 & 0.006 & 0.197 & 2.643 & 0.009 \\
\hline LDL-Cholesterol (mg/dl) & 0.004 & 0.001 & 0.273 & 3.778 & 0.001 \\
\hline
\end{tabular}




\section{Discussion}

Occupational noise exposure levels reported in this study could be considered accepted according to the permissible level of exposure adopted by the Egyptian law (The Prime Minister Decision No 338/1995). However, this personal dosimeter sound pressure level around 90 dBA eight hours TWA for high noise exposed group exceeded other international safe level criteria (HSE, 2006). Safe noise exposure level below $85 \mathrm{dBA}$ eight hours TWA was suggested in relation to noise induced auditory effects. The existence of other possible health effects above this level is claimed (Van Kempen, et al., 2002). None of the workers exposed to high or low noise in the present study reported the use of ear protective equipment claiming that it is uncomfortable and inconvenient.

The present work revealed that noise annoyance was significantly highly perceived by workers exposed to high noise level in comparison to those exposed to lower level and the non exposed group. Also, a positive association between perceived noise annoyance and the outcome of the suggested predictive test was observed both in univariate and multivariate analyses of this study. The currently studied three groups were similar in life style factors including BMI, smoking and physical activity, as well as socio-demographic factors including education and marital status. This is going with the studies of Smith, 1991 and Hygge, et al., 2003 who demonstrated a possible relation between annoyance to noise exposure and personality factors affecting performance irrelevant of other factors. On the contrary, Lijungberg, and Neely, 2007 stated that perceived noise annoyance may be influenced not only by personality characteristics, but also by lifestyle factors especially among the noise sensitive subjects. Such discrepancies may be due to different population criteria and different exposure conditions.

In addition, the present findings showed a significant positive relation between the increase in resting $\mathrm{HR}, \mathrm{TC}$ and LDL-C among noise exposed workers mainly those with high exposure level. This is coinciding with the work of Tomei, et al., 2010 in a recent meta-analysis, as higher levels of resting heart rate, blood pressure and atherogenic metabolic parameters were observed in relation to high noise exposure than with low exposure. Neurohormonal activation and increased sympathetic drive may be possible stress mediated mechanisms behind these hemodynamic and metabolic changes. On the contrary, the previous study of Ljungberg, and Neely, 
2007 claimed that metabolic changes in the form of elevated cortisol levels may not be correlated with sound pressure levels. The explanation was that workers with chronic noise exposure may tend to under-estimate stress due to self-adaptation.

The present study draws the attention for early prediction of those at high cardiovascular risk in relation to occupational noise exposure. Exaggerated blood pressure response at exercise was used as a possible predictive tool. This coincides with the aim of other studies in prediction of cardiovascular risk among noise exposed workers, but they used other parameters including ambulatory blood pressure monitoring (Green, et al., 1991; Fogari, et al., 2001), autonomic cardiovascular functions (Baudrie, et al., 1997) and ambulatory vascular properties in terms of resistance, compliance and distensibility (Chang, et al., 2007). The currently used test is easier, cheaper and informative with high degree of reproducibility and predictivity as evidenced in other followup studies investigating the relation of positive outcome of this test and future outcome of cardiovascular disease (Dlin, et al., 1983; Lim, et al., 1996). This test may be used to uncover a subtle cardiovascular disorder that was not apparent at rest. In the current work, exaggerated BP response at exercise was significantly positively related to coronary risk factors including $\mathrm{Wt}, \mathrm{BMI}$, SI, family history of premature CAD, physical inactivity, resting HR, resting SBP, resting DBP, TC, LDL-C and TG. Such risk factors may explain the lower fitness level among exaggerated BP responders in this study than normal responders as measured by exercise time and work capacity units. The present findings demonstrated that this predictive test has a reasonable level of sensitivity (77.4\%) and a very good degree of specificity $(84.6 \%)$ in risk stratification of cases with 3 risk factors or more.

Workers below 50 years were only included in the current study to make value for the predictivity of this test among apparently healthy noise exposed workers. Logistic regression revealed the significant effect of noise exposure level on the positive outcome of this risk predictive test together with perceived noise annoyance, resting HR and LDL-cholesterol. Although, some of these variables are inter-correlated, yet, the observed independent effect of each may denote other possible risk mechanisms related to noise exposure level. This was explained by Talbott, et al., 1999 who reported a dose-response relationship between occupational noise and blood pressure per se. On the other hand, Chang, et al., 2007 described sustained changes in 
vascular properties suggesting endothelial damage in male workers with high occupational noise exposure. The observed significance for annoyance may be a possible inducing factor for early phases of cardiovascular risk as measured in this study. Also, in the current setting, noise exposure at $90 \mathrm{dBA}$ as TWA may be unsafe for potential cardiovascular risk and even at lower levels.

\section{Conclusion and Recommendations}

Exaggerated BP response at exercise may be a reasonable predictive test for cardiovascular risk among noise exposed workers. This test was especially related to noise exposure level and perceived noise annoyance each independent from the other. Also it was significantly dependent on resting HR and LDL-cholesterol.

This cardiovascular risk predictive test may be recommended for application in occupational health preventive programs for surveillance of workers exposed to noise.

Noise control is essential through environmental measures and the proper use of suitable and comfortable ear protective equipment. Also, noise exposed workers should receive attention for cardiovascular risk reduction and healthy life-style modification through workers' health education.
Further follow-up studies are needed in this area to suggest a cardiovascular safe noise exposure level.

\section{Abbreviations}

TWA, time weighted average; SBP, systolic blood pressure; DBP, diastolic blood pressure; BP, blood pressure; HR, heart rate; TC, total cholesterol; LDL-C, low density lipoprotein-cholesterol; HDL-C, high density lipoprotein-cholesterol; SI, smoking index; CAD, coronary artery disease; Ht, height; Wt, weight; BMI, body mass index; \%MPHR, percent achieved of maximal predicted heart rate.

\section{References}

1. Abbate, C., Giorgianni, C., Munao, F., Costa, C., Brecciaroli, R. and Barbaro, M. (2002). "Effects of noise on functional cardiovascular parameters: A follow-up study." G. Ital. Med. Lav. Ergonom. 24(1): 43-8.

2. Babisch, W., Ising, H. and Gallacher, J.E.J. (2003). "Health status as a potential effect modifier of the relation between noise annoyance and incidence of ischemic heart disease." Occup. Environ. Med. 60: 739-45.

3. Balkau, B., Shipley, M., Jarrett, R.J., Pyorala, K., Pyorala, M., Forhan, A. and Eschwege, E. (1998). "High blood glucose concentration is a risk factor for mortality in middle-aged nondiabetic men: 20-year follow-up in the Whitehall Study, the Paris Prospective Study, and the Helsinki Policemen Study.” Diabetes Care. 21: 360-7.

4. Baudrie, V., Tulen, J.H.M., Blanc, J. and Elghozi, J.L. (1997). "Autonomic components of the cardiovascular responses to an acoustic 
startle stimulus in rats." J. Auton. Pharmacol. 17: 303-9.

5. Borg, G. (1998). "Borg's perceived exertion ad pain scales.” Champaign, IL: Human Kinetic.

6. Buchfuhre, M.J., Hansen, J.E., Robinson, T.E., Sue, D.Y., Wasserman, K. and Whipp, B.J. (1983). "Optimizing the exercise protocol for cardiopulmonary assessment.” J. Appl. Physiol. 55: 1558-64.

7. Chang, T.Y., Jain, R.M., Wang, C.S. and Chan, C.C. (2003). "Effects of occupational noise exposure on blood pressure." J. Occup. Environ. Med. 45: 1289-96.

8. Chang, T., Su, T., Lin, S., Jain, R. and Chan, C. (2007). "Effects of occupational noise exposure on 24-hour ambulatory vascular properties in male workers.” Environ. Health Presp. 115(11): 1660-4.

9. Davies, H.W., Teschke, K., Kennedy, S.M., Hodgson, M.R., Hertzman, C. and Demers, P.A. (2005). "Occupational exposure to noise and mortality from acute myocardial infarction." Epidemiology. 16: 25-32.

10. Dlin, R.A., Hanne, N., Silverberg, D.S. and BarOr, O. (1983). "Follow-up of normotensive men with exaggerated blood pressure response to exercise.” Am. Heart. J. 106: 316-20.

11. ESH and ESC (2007). "European Society of Hypertension and European Society of Cardiology. 2007 guidelines for the management of arterial hypertension." European heart journal doi: 10. 1093/eurheartj/ehm236.

12. Filipousky, J., Ducimetiere, P. and Safar, M. (1992). "Prognostic significance of exercise blood pressure and heart rate in middle-aged men." Hypertension. 20: 337-9. OS.

13. Fogari, R., Zoppi, A., Corradi, L., Marasi, G., Vanasia, A. and Zanchetti, A. (2001). "Transient but not sustained blood pressure increments by occupational noise. An ambulatory blood pressure measurement study." J. Hypertens. 19: 1021-7.
14. Friedewold, W.T., Levy, R.I. and Fredricson, D.S. (1972). "Estimation of the concentration ultracentrifuge." Clin. Chem. 18: 499-502.

15. Giordano, C., Conticello, S., Beatrice, F., Montemagno, A. and Boggero, R. (2001). "Non-auditory effects of environmental noise: a study of metallurgical and mechanical workers." Acta. Otorhinolaryngol. Ital. 21(5): 281-6.

16. Green, M.S., Schwartz, K., Harari, S. and Najenson, T. (1991). "Industrial noise exposure and ambulatory blood pressure and heart rate." J. Occup. Med. 1991; 33(8): 879-83.

17. Hassall, J.R. and Zaveri, K. (2006). "Acoustic noise measurements." 4th ed. Bruel and Kjear. Naerum, Denmark. pp: 75-130. HSE. Noise, health and safety. Executive. http://www.hse. gov.uk/noise >

18. Hygge, S., Boman, E. and Enmarker, I. (2003). "The effect of road traffic noise and meaningful irrelevant speech on different memory systems.” Scand. J. Psychol. 44(1): 13-21.

19. Ilia, R., Carmel, S., Tsatskis, B. and Gueron, M. (1998). "Exaggerated blood pressure response at exercise in normotensive subjects: Demographic and stress performance characteristics." Am. Heart J. 136: 499-503.

20. Kjeldsen, S.E., Mundal, R., Sandvik, L., Erikssen, G., Thaulow, E. and Erikssen, J. (2001). "Supine and exercise systolic blood pressure predict cardiovascular death in middle-aged men.” J. Hypertens. 19: 1343-8. OS.

21. Lim, P.O., MacFadyen, R.J., Clarkson, P.B.M. and MacDonald, T.M. (1996). "Impaired exercise tolerance in hypertensive patients." Ann. Int. Med. 124: 41-55.

22. Ljungberg, J.K. and Neely, G. (2007). "Stress, Subjective experience and cognitive performance during exposure to noise and vibration." J. Environ. Psychol. 27: 44-54.

23. Lusk, S.L., Hagerty, B.M., Gillespie, B. and Caruso, C.C. (2002). "Chronic effects of work place noise on blood pressure and heart rate." Arch. Environ. Health. 57: 273-81. 
24. Monolio, T.A., Burke, G.L., Savage, P.J., Sidney, S., Gardin, J.M. and Oberman, A. (1994). "Exercise blood pressure response and 5-year risk of elevated blood pressure in a cohort of young adults: The CARD1A study." Am. J. Hypertens. 7: 234-41.

25. NCEP. (1994). "National Cholesterol Education Program. Second report of the expert Panel on Detection, Evaluation, and Treatment of high blood cholesterol (Adult Treatment Panel II)." Circulation. 89: 1333-445.

26. Rose, G.A., Blackburn, H., Gillum, R.F. and Prineas, R.J. (1982). "Cardiovascular survey methods." 2nd ed. Geneva, WHO.

27. Singh, J.P., Lkarson, M.G., Manolio, T.A., O'Donnell, C.J., Lauer, M., Evans, J.C. and Levy, D. (1999). "Blood pressure response during treadmill testing as a risk factor for new-onset hypertension: the Framingham heart study." Circulation. 99: 1831-6. OS.

28. Smith, A.P. (1991). "Noise and aspects of attention.” B. J. Psychol. 82: 313-24.

29. Talbott, E.O., Gibson, L.B., Burks, A., Engberg, R. and McHugh, K.P. (1999). "Evidence for a dose-response relationship between occupational noise and blood pressure." Arch. Environ. Health. 54(2): 71-8.

30. The Prime Minister Decision (No 338/1995). "The Decree Law of the Environment 4/1994." Executive Legislation. Cairo, Egypt. (in Arabic)
31. Thompson, S.J. (1993). "Review: Extra-aural health effects of chronic noise exposure in humans." Schriftenr. Ver. Wasser. Boden. Lufthyg. 88: 91-117.

32. Tomei, F., Fantini, S., Tomao, E., Baccolo, T.P. and Rosati, M.V. (2002). "Hypertension and chronic exposure to noise." Arch. Environ. health. 55: 319-25.

33. Tomei, G., Fioravanti, M., Cerratti, D., Sancini, A., Tomao, E., et al., (2010). "Occupational exposure to noise and the cardiovascualr system: Ameta-analysis." Science Total Environ. 408: 681-9.

34. Van Kempen, E.E.M.M., Kruize, H., Boshuizen, H.C., Ameling, C.B., Staatsen, B.A.M. and de Hollander, A.E.M. (2002). "The association between noise exposure and blood pressure and ischemic heart disease: a meta-analysis." Environ. Health Perspect. 110: 307-17.

35. Virkkunen, H., Kauppinen, T. and Tenkanen, L. (2005). "Long-term effect of occupational noise on the risk of coronary heart disease." Scand. J. Work Environ. Health. 31: 291-9.

36. Willich, S.N., Wegscheider, K., Stallmann, M. and Keil, T. (2006). "Noise burden and the risk of myocardial infarction." Eur. Heart J. 27: 27682.

37. World Health Organization (WHO, 2006). "Obesity and overweight." Geneva: WHO Fact Sheet 311. 